\title{
Photocatalytic ZnO-Assisted Degradation of Spiramycin in Urban Wastewater: Degradation Kinetics and Toxicity
}

\author{
Davide Anselmo Luigi Vignati $^{1}{ }^{(0)}$, Giusy Lofrano ${ }^{2, *}$, Giovanni Libralato ${ }^{3}\left({ }^{\circ}\right.$, Marco Guida $^{2,3}{ }^{(0)}$, \\ Antonietta Siciliano ${ }^{3}$, Federica Carraturo ${ }^{3}$ (1) and Maurizio Carotenuto $^{4}$ \\ 1 Université de Lorraine, CNRS, LIEC, F-57000 Metz, France; david-anselmo.vignati@univ-lorraine.fr \\ 2 Centro Servizi Metrologici e Tecnologici Avanzati (CeSMA), University of Naples Federico II, Via Cinthia 21, \\ 80126 Naples, Italy; marco.guida@unina.it \\ 3 Department of Biology, University of Naples Federico II, via Cinthia ed. 7, 80126 Naples, Italy; \\ giovanni.libralato@unina.it (G.L.); antonietta.siciliano2@unina.it (A.S.); federica.carraturo@unina.it (F.C.) \\ 4 Department of Chemical and Biology "A. Zambelli", University of Salerno, via Giovanni Paolo II 132, \\ 84084 Fisciano (SA), Italy; mcarotenuto@unisa.it \\ * Correspondence: glofrano@unisa.it or giusylofrano@gmail.com
}

Citation: Vignati, D.A.L.; Lofrano,

G.; Libralato, G.; Guida, M.; Siciliano,

A.; Carraturo, F.; Carotenuto, M.

Photocatalytic ZnO-Assisted

Degradation of Spiramycin in Urban

Wastewater: Degradation Kinetics

and Toxicity. Water 2021, 13, 1051.

https://doi.org/10.3390/w13081051

Academic Editor: Jiangyong Hu

Received: 25 January 2021

Accepted: 3 April 2021

Published: 11 April 2021

Publisher's Note: MDPI stays neutral with regard to jurisdictional claims in published maps and institutional affiliations.

Copyright: (c) 2021 by the authors. Licensee MDPI, Basel, Switzerland. This article is an open access article distributed under the terms and conditions of the Creative Commons Attribution (CC BY) license (https:// creativecommons.org/licenses/by/ $4.0 /)$.

\begin{abstract}
The removal of contaminants of emerging concern from urban wastewater treatment plants (WWTPs) remains a challenge to promote safe wastewater reuse practices. Macrolides are the most abundant antibiotics detected in untreated wastewater and their concentration in WWTPs effluents is only partially reduced by conventional treatments. Among several advanced oxidation processes (AOPs), photocatalysis has demonstrated the capability to effectively remove pharmaceuticals from different aqueous matrices. Recently, $\mathrm{ZnO}$ has emerged as an efficient, promising, and less expensive alternative to $\mathrm{TiO}_{2}$, due to its photocatalytic capability and attitude to exploit better the solar spectrum than $\mathrm{TiO}_{2}$. In this study, the behaviors of $\mathrm{ZnO}$ photocatalysis were evaluated using a representative macrolide antibiotic, spiramycin (SPY), in aqueous solutions and urban wastewater. After 80 min of photocatalysis, 95-99\% removal of SPY was achieved at $1 \mathrm{~g} \mathrm{~L}^{-1} \mathrm{ZnO}$ concentrations in aqueous solutions and wastewater, respectively. After treatment, the effluent toxicity, evaluated using the bacterium Aliivibrio fischeri, the green alga Raphidocelis subcapitata, and the crustacean Daphnia magna ranged between slight acute and high acute hazard. Filterable and ultrafilterable $\mathrm{Zn}$ concentrations were quantified in treated effluents and shown to be high enough to contribute to the observed toxicity.
\end{abstract}

Keywords: antibiotics; photocatalysis; zinc oxide; wastewater

\section{Introduction}

Many contaminants of emerging concern (CECs) in wastewaters (WWs) and surface waters (SWs) are recalcitrant to conventional wastewater treatment processes and hence persistent in the environment [1,2]. Antibiotics are among the main CECs detected in aquatic environments at concentrations ranging from nanograms per liter (e.g., in river water) up to milligrams per liter (e.g., in hospital wastewater) [3] and hundreds of milligrams per liter in antibiotic production wastewater [4]. The benefits they produce for controlling infectious diseases have often led to underestimate their adverse one-health effects. Their amount for human and veterinary use has increased year by year, with growing concerns for human health due to the enhancement of bacterial antibiotic resistance, concomitantly with damage to beneficial bacteria [5]. According to the World Health Organization [6], $80 \%$ of the total antibiotic consumption can be attributed to veterinary use. Considering a total consumption of 200,000 tons / year, the United Nations General Assembly has recognized the veterinary use of antibiotics as one of the primary causes for the increase of antimicrobial resistance [7]. Macrolides, particularly clarithromycin, spiramycin (SPY), and quinolones are the most abundant antibiotics in untreated wastewater. The European 
Center for Disease Control [8] estimated that macrolides are the third class of antibiotics consumed in Italy after penicillin and quinolones.

The presence of antibiotics may limit agricultural wastewater reuse due to their possible uptake by crops irrigated with WWTPs effluents [9]. The rising competition for water resources increasingly pushes societies toward water reuse which, without the necessary precautions, may result in potential health risks for humans and the environment. Water scarcity, poor wastewater management, and high water demand for irrigation may transfer significant contaminant loads to farms and possibly to foodstuffs [10]. The spreading of antibiotic resistance including antibiotic-resistant bacteria and antibiotic resistance genes is also of utmost concern. At very low antibiotics concentrations, bacteria are not killed and can develop genes to protect themselves against antibiotics. These genes can then propagate across bacterial strains [11-13]. Without further action, ten million people may die each year worldwide due to infectious diseases caused by multi-resistant bacteria by 2050 [14].

In this framework, the availability of reliable technologies for antibiotic removal from water and wastewater is a top priority to guarantee access to safe water for people worldwide [15].

The development of new methods to address antibiotic pollution is an active research field. Conventional physico-chemical methods usually show low pollutant removal rates, because of expensive reagents with low stability and poor recycling potential. Biodegradation techniques are more interesting from a sustainability point of view but hampered by the recalcitrant nature of these contaminants. Advanced oxidation processes are therefore currently considered the most valid alternative for antibiotics removal from wastewater. In particular, photocatalysis is an economic, efficient, green technology for degrading antibiotics using sunlight and ambient conditions [16,17].

$\mathrm{TiO}_{2}$-assisted photocatalysis has been widely studied for the degradation of several classes of antibiotics. However, its application in full-scale treatment is strongly limited by the cost associated with the use of UV light and the difficulty of removing $\mathrm{TiO}_{2}$ nanoparticles from treated effluents. Zinc oxide $(\mathrm{ZnO})$, with a direct bandgap of approximately $3.3 \mathrm{eV}$ has been suggested as an effective and cheaper alternative to $\mathrm{TiO}_{2}$ because of its strong oxidation ability, good photocatalytic properties, and a large free-excitation binding energy. Moreover, $\mathrm{ZnO}$-based catalysts are considered more suitable for solar-driven photocatalysis because $\mathrm{ZnO}$ can absorb a larger fraction of the solar spectrum than $\mathrm{TiO}_{2}$ thanks to its direct and wide bandgap in the near-UV spectral region. $\mathrm{ZnO}$ is also a good antibacterial agent being stable under harsh processing conditions [18,19]. ZnO-assisted photocatalytic degradation showed its ability to remove several wastewater contaminants including 1,4-dioxane, trihalomethanes (THMs), triclosan (TCS), triclocarban (TCC), antibiotic resistance bacteria (ARB), and antibiotic resistance genes (ARGs) under a low intensity of UV exposure [20]. Other studies investigated the potential of $\mathrm{ZnO}$ for the photodegradation of perfluoroalkyl acids [21], caffeine [22], or several dyes [23]. Most literature studies established the optimum reaction conditions on the basis of $\mathrm{pH}$, temperature, light intensity, morphological structure, and photocatalyst amount [24]. However, complete degradation of the target chemicals does not ensure that final effluents are free from residual toxicity [25], possibly due to the formation of toxic transformation products [26,27].

In this study, ZnO-assisted photocatalysis to degrade spiramycin (SPY) was investigated using a range of $\mathrm{ZnO}$ concentrations in both spiked aqueous solutions and urban treated wastewater samples looking for process optimization. A battery of bioassays was used to fully characterize the performance of the treatment process.

\section{Materials and Methods}

\subsection{Experimental Procedure}

A $200 \mathrm{~mL}$ aliquot of the antibiotic aqueous solution (10 $\mathrm{mg} \mathrm{L}^{-1}$ of SPY) was placed in a $250 \mathrm{~mL}$ magnetically stirred cylindrical Pyrex vessel and illuminated with a xenon arc lamp (450 W, Lot Oriel Group, Italy). The illumination chamber was equipped with 
special glass allowing the transmission of wavelengths below $320 \mathrm{~nm}$; i.e., the radiation able to activate $\mathrm{ZnO}$ for photocatalysis experiments. The effects of $\mathrm{ZnO}$ dose (0.1, $0.5,1,2$, and $4 \mathrm{~g} \mathrm{ZnO} \mathrm{L}^{-1}$ ) were evaluated at $20{ }^{\circ} \mathrm{C}$ and $\mathrm{pH}=5.5 \mathrm{in}$ aqueous solutions (ultrapure water spiked with SPY). Samples were taken at reaction times of 5, 10, 20, $40,60,80$, and $120 \mathrm{~min}$ using a syringe and filtered through $0.45 \mu \mathrm{m}$ membrane filters for the determination of SPY concentration by high-performance liquid chromatography (HPLC). The degradation of SPY due to UV irradiation per se was also studied. Preliminary experiments to determine the potential adsorption of SPY were carried out in the dark. Experiments were performed at least in duplicate and are reported as arithmetic mean and semi-dispersion. After process optimization in ultrapure water, biologically treated wastewater (BTW) taken from a municipal wastewater treatment plant $\left(\mathrm{pH}=6.5 ; \mathrm{BOD}_{5}=18 \mathrm{mg} / \mathrm{L} ; \mathrm{COD}=48.5 \mathrm{mg} / \mathrm{L} ;\right.$ Total Suspended Solids TSS $=46 \mathrm{mg} / \mathrm{L} ;$

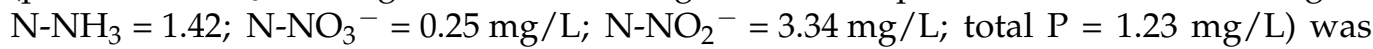
spiked with $10 \mathrm{mg} \mathrm{L}^{-1}$ of SPY to evaluate the effect of a real matrix on the process efficiency. BTW samples were taken from the effluent of the biological treatment step just upstream of the disinfection unit. Samples were collected in $25 \mathrm{~L}$ tanks and stored at about $4{ }^{\circ} \mathrm{C}$ during transport and prior to experiments.

\subsection{Chemicals and Analytical Methods}

Zinc oxide (ZnO, m.w. 81.39, purity $\approx 80 \%)$ and SPY $\left(\mathrm{C}_{43} \mathrm{H}_{74} \mathrm{~N}_{2} \mathrm{O}_{14} ; 443.053 \mathrm{~g} \mathrm{~mol}^{-1}\right.$; solid appearance: white or yellow-white powder) were supplied by Sigma-Aldrich (Saint Louis, MO, USA). Sigma Aldrich also supplied high-performance liquid chromatography (HPLC) grade water, methanol, acetonitrile, and formic acid. The degradation of SPY dispersed in ultrapure water was followed by HPLC-UV (Finnigan Surveyor LC Pump Plus, Carlsbad, CA, USA) equipped with a reversed-phase C18 analytical column (Phenomenex Luna, $3 \mu \mathrm{m}, 2.1 \mathrm{~mm} \times 150 \mathrm{~mm}$ ) with UV-Vis spectrophotometer (Finnigan Surveyor UV-VIS Plus Detector, USA). The compound was eluted using a mixture of $0.1 \%$ formic acid in water (eluent $A$ ) and $0.1 \%$ formic acid in acetonitrile-methanol (1:1 v:v) (eluent $B$ ) at a flow rate of $0.2 \mathrm{~mL} \mathrm{~min}^{-1}$ as mobile phase. The initial concentration was $10 \% \mathrm{~B}$ followed by a linear gradient from 10 to $70 \%$ B over the course of $3 \mathrm{~min}$ and to $80 \%$ over the next $2 \mathrm{~min}$. Finally, eluent B was lowered to $10 \%$ in $1 \mathrm{~min}$. The system was left to equilibrate for 9 min between injections. The injection volume was $20 \mu \mathrm{L}$ and the wavelength set for the quantification was $230 \mathrm{~nm}$ corresponding to the maximum light absorption of SPY. Under these conditions, the retention time of SPY was about $9.7 \mathrm{~min}$ (Figure 1). The limit of quantification (LOQ) was $0.1 \mu \mathrm{g} \mathrm{mL}^{-1}$. Data were collected using ChromQuest software version 3.1.6 (Thermo Electron 2003).

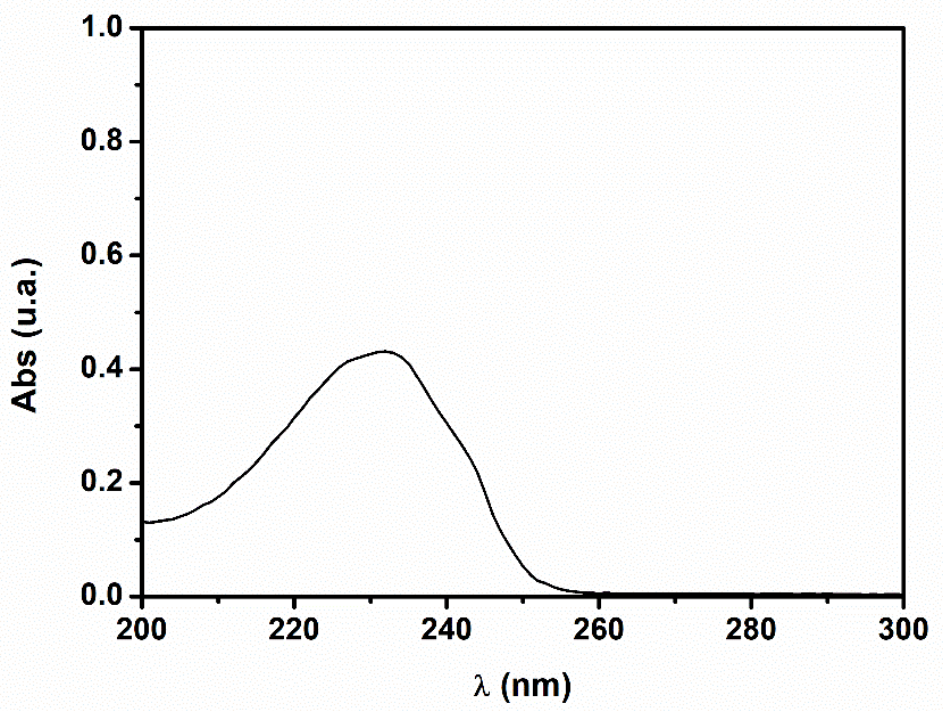

Figure 1. UV spectra of spiramycin (SPY) $\left(1 \mathrm{mg} \mathrm{L}^{-1}\right)$ in distilled water. 
Zinc concentrations ( $\mathrm{Zn}$ ) were determined by Flame Atomic Absorption Spectroscopy (FAAS) after filtration at $0.45 \mu \mathrm{m}$ (Millex HA syringe filters, mixed cellulose esters, Millipore, reference SLHA033SS, lot R5EA08092) and, for selected samples, ultrafiltration at $3 \mathrm{kDa}$ (Amicon ${ }^{\circledR}$ Ultra-15 centrifugal filter units, reference UFC900396). Before use, filters were rinsed twice with $150 \mathrm{~mL}$ of ultrapure water and a volume of the second rinse were collected for Zn blank determinations. Ultrafiltration units were cleaned by introducing $10 \mathrm{~mL}$ of ultrapure water in their upper parts and centrifuged for $20 \mathrm{~min}$ at $4000 \mathrm{rpm}$ (3500 g) using a HERMLE Z300 centrifuge with a swinging bucket rotor. A second aliquot of ultrapure water was subsequently ultracentrifuged and used for blank determination.

\subsection{Ecotoxicity}

A battery of acute (A) and chronic (C) toxicity tests were performed with biological models belonging to various trophic levels: the bacterium Aliivibrio fischeri (A), the green alga Raphidocelis subcapitata (C), and the crustacean Daphnia magna (A). Tests were carried out on (i) $10 \mathrm{mg} \mathrm{L}^{-1} \mathrm{SPY}$ solution after the photocatalytic treatment with various $\mathrm{ZnO}$ concentrations $\left(0.1,0.5,1.0,2.0\right.$, and $\left.4.0 \mathrm{~g} \mathrm{~L}^{-1}\right)$ for $120 \mathrm{~min}$, (ii) biologically treated wastewater (BTW) and, (iii) BTW spiked with $10 \mathrm{mg} \mathrm{L}^{-1}$ of SPY and treated by $\mathrm{ZnO}$ photocatalysis. Toxicity tests on untreated $10 \mathrm{mg} \mathrm{L}^{-1}$ SPY solution (pure substance) were previously carried out. Readers are referred to [26] the corresponding quality assurance/quality control procedures. All toxicity tests included negative and positive controls in accordance with the specific reference methods. Toxicity was expressed as a percentage of effect or as effective concentration causing the 5\% (EC 5$), 20 \%\left(\mathrm{EC}_{20}\right)$, and $50 \%\left(\mathrm{EC}_{50}\right)$ effect to the exposed population. After verification of homoscedasticity ( $\mathrm{F}$ test, $p<0.05$ ) and normality (Shapiro-Wilk test, $p<0.05$ ) of toxicity data, the presence of significant differences between different experimental treatments and controls was assessed by analysis of variance (ANOVA, $p<0.05$ ). When ANOVA revealed significant differences among treatments, post-hoc comparisons were carried out with Tukey's test $(p<0.05)$. Statistical analyses were performed using SigmaPlot version 11.0 (Systat Software, Inc., San Jose CA, USA). Since $\mathrm{ZnO}$ nanoparticles are known to be progressively dissolved in aqueous matrices, aliquots of each test solution were assayed for their filterable $(0.45 \mu \mathrm{m})$ and ultrafilterable $(3 \mathrm{kDa})$ Zn concentrations.

\section{Results}

\subsection{Kinetic Studies in Distilled Water}

Experiments carried out in the dark in distilled water at a concentration of $1 \mathrm{~g} \mathrm{~L}^{-1}$ of $\mathrm{ZnO}$ proved that SPY removal by adsorption was negligible. According to previous studies [26], a slight decrease in SPY concentration (10\%) could be observed during the photolysis experiments. The rather poor SPY removal kinetics and efficiencies obtained via photolysis and dark processes were improved by increasing $\mathrm{ZnO}$ concentration in the photocatalysis process due to increased $\mathrm{OH}^{\bullet}$ production (Table 1). As shown in Figure 2, a percentage SPY removal of $76 \%, 81 \%, 95 \%, 97 \%$, and $91 \%$ was achieved after $80 \mathrm{~min}$ irradiation at $\mathrm{ZnO}$ concentrations of $0.1,0.5,1.0,2.0$, and $4.0 \mathrm{~g} / \mathrm{L}$, respectively. After 120 min of photocatalysis, a $>99 \%$ removal of SPY was achieved at all $\mathrm{ZnO}$ concentrations except $0.1 \mathrm{~g} \mathrm{~L}^{-1}$.

Table 1. Photocatalytic kinetic constants of SPY $\left(10 \mathrm{mg} \mathrm{L}^{-1}\right)$ at $0.1,0.5,1.0,2.0$, and $4.0 \mathrm{~g} \mathrm{~L}^{-1}$ of $\mathrm{ZnO}$ at $\mathrm{pH}=5.5$. The numbers in brackets are the kinetic constants standard errors.

\begin{tabular}{ccc}
\hline $\mathbf{C}_{\mathbf{Z n O}}\left(\mathbf{g ~ L}^{-\mathbf{1}}\right)$ & $\mathbf{k}\left(\mathbf{m i n}^{-\mathbf{1}}\right)$ & $\boldsymbol{t}_{\mathbf{1 / 2}}(\mathbf{m i n})$ \\
\hline 0.1 & $0.0186(0.0008)$ & $37.3(1.6)$ \\
0.5 & $0.049(0.002)$ & $14.1(0.6)$ \\
1.0 & $0.0471(0.0009)$ & $14.7(0.3)$ \\
2.0 & $0.060(0.004)$ & $11.6(0.8)$ \\
4.0 & $0.085(0.006)$ & $8.2(0.6)$ \\
\hline
\end{tabular}




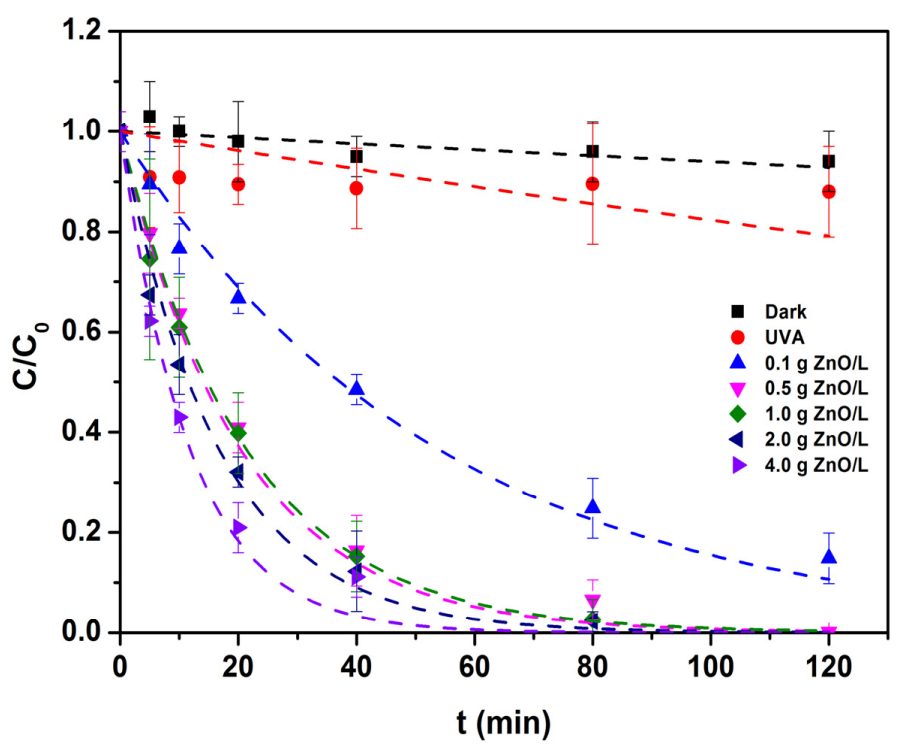

Figure 2. Photocatalytic kinetic curves of SPY removal (initial concentration $10 \mathrm{mg} \mathrm{L}^{-1}$ ) after 5, 10, 20, 40, 80, and $120 \mathrm{~min}$ at $0.1,0.5,1.0,2.0$, and $4.0 \mathrm{~g} \mathrm{~L}^{-1}$ of $\mathrm{ZnO}$ and $\mathrm{pH}=5.5$; error bars represent the standard error $(n=3)$.

The increase of $\mathrm{ZnO}$ concentration above $1 \mathrm{~g} \mathrm{~L}^{-1}$ did not produce any significant improvement in antibiotic degradation and the rate of degradation remained almost unchanged. This may be due to reduced UV light penetration because of increasing turbidity and, thus, a corresponding decrease in the photoactivated volume of the suspension. The photocatalytic reaction approximately followed a pseudo-first-order kinetics according to Equation (1) [28,29]:

$$
\frac{C_{t}}{C_{0}}=\exp ^{-k t}
$$

where $C_{t}$ and $C_{0}$ are the concentrations of SPY at time $t$ and time zero, respectively; $k$ is the pseudo-first-order rate constant for the SPY degradation $\left(\mathrm{min}^{-1}\right)$ and $t$ is time ( $\mathrm{min}$ ). The photocatalytic degradation rate constants are reported in Table 1 with the half-life $\left(t_{1 / 2}\right)$ values.

Comparing the results from [26], the $\mathrm{TiO}_{2}$ assisted photocatalytic degradation of $10 \mathrm{mg} \mathrm{L}^{-1}$ SPY had higher photocatalytic performance, which is mainly attributed to the lowest transfer barrier of electrons as well as the low recombination rate of the charge carriers [24]. These results agree with studies available in the scientific literature [25]. For $\mathrm{TiO}_{2}$, superoxide radicals $\left(\mathrm{O}_{2}^{--}\right)$and holes $\left(\mathrm{h}^{+}\right)$play a key role in the degradation process, while for $\mathrm{ZnO}$ superoxide radicals $\left(\mathrm{O}_{2}^{\bullet-}\right)$ and hydroxyl $\left(\mathrm{OH}^{\bullet}\right)$ radicals are the predominant reactive species in the degradation process.

The chemical structure of the target molecule can influence the reaction at the surface and determine a slower removal rate. Thus, while efficiency in the generation of reactive oxygen species is of high importance in evaluating the efficacy of the photocatalysts, it is not the sole substantial contributor [30,31]. Zammit et al. [13] observed a very different behavior in the degradation of two antibiotics by $\mathrm{TiO}_{2}$ and $\mathrm{ZnO}$ photocatalysis, reporting different degradation rates for the two photocatalysts with respect to trimethoprim and sulfamethoxazole.

\subsection{Kinetic Studies in Wastewater}

Considering the results obtained with aqueous solutions, a $\mathrm{ZnO}$ amount of $1 \mathrm{~g} \mathrm{~L}^{-1}$ was used to investigate SPY removal in BTW. The observed trend was similar to those of experiments carried out in distilled water with $99 \%$ of SPY removal after $80 \mathrm{~min}$ of photocatalytic treatment (Figure 3). This result compares favorably with the 95\% SPY degradation in ultrapure water (see Section 3.1), confirming the technical validity of the 
proposed procedure for real-world effluents. The high percent degradation of SPY likely reflects a very low concentration of scavenger compounds, including organics, in the BTW. Under such conditions, the radical species remained available for the oxidation of the target pollutant.

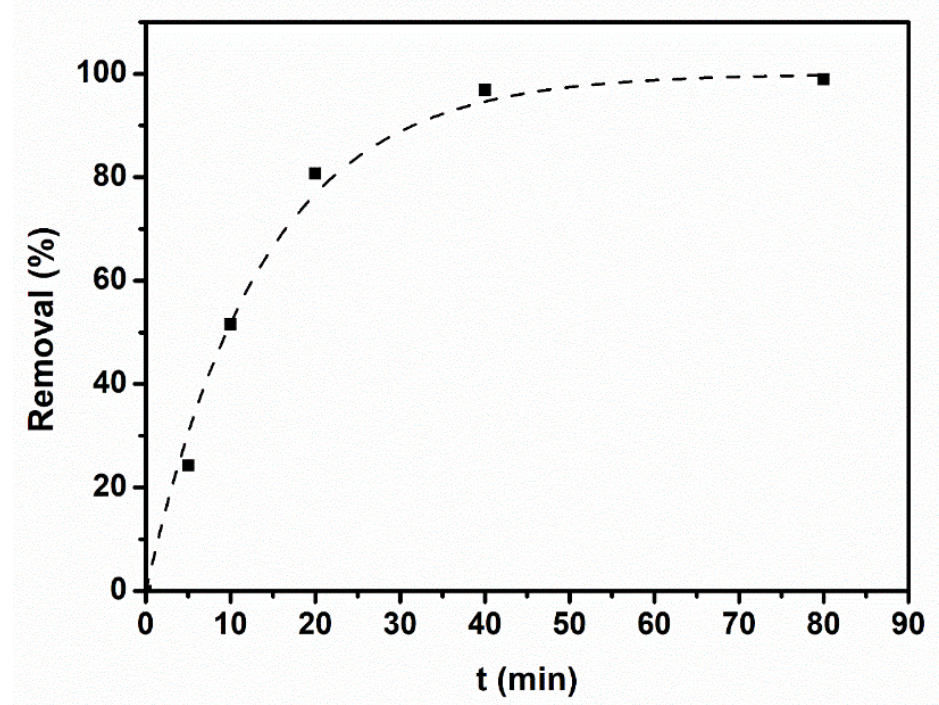

Figure 3. SPY $\left(10 \mathrm{mg} \mathrm{L}^{-1}\right)$ removal efficiency trend after $5,10,20,40$, and $80 \mathrm{~min}$ at $1.0 \mathrm{~g} \mathrm{~L}^{-1}$ of $\mathrm{ZnO}$.

\section{3. $\mathrm{ZnO}$ Residue Studies}

Filtration and ultrafiltration Zn blank values $(\mathrm{n}=8)$ were $30 \pm 20 \mu \mathrm{g} \mathrm{L}^{-1}$, and below the detection limit, respectively. Concentrations for all samples, including ultrafiltered sample aliquots, were therefore corrected for the corresponding filterable blank values (Figure 4). Blank correction for ultrafiltered samples was necessary because ultrafiltration was performed after filtration at $0.45 \mu \mathrm{m}$. Blank corrected $\mathrm{Zn}$ concentrations in the effluent of the municipal wastewater treatment plant were $150 \mu \mathrm{g} \mathrm{L}^{-1}(<0.45 \mu \mathrm{m})$ and $99 \mu \mathrm{g} \mathrm{L}^{-1}$ $(<3 \mathrm{kDa})$. Duplicate measurement of filtered sample aliquots differed by less than $10 \%$.

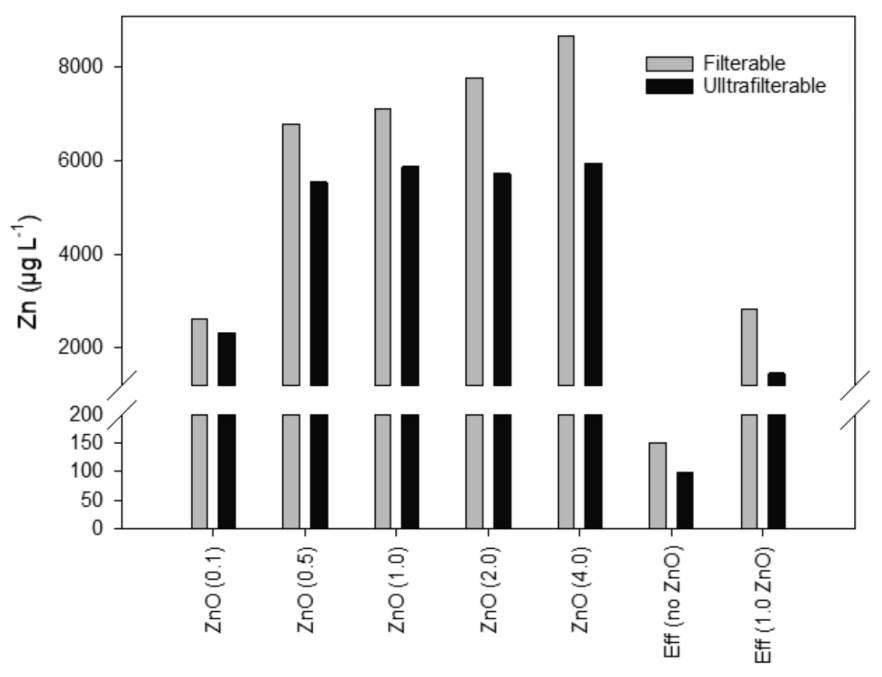

Figure 4. Total $\mathrm{Zn}$ recovery after filtration and ultrafiltration from distilled water spiked with $0.1,0.5$, 1, 2, and $4 \mathrm{~g} \mathrm{~L}^{-1} \mathrm{ZnO}$ and biologically treated wastewater (Eff) with (1.0 $\mathrm{g} \mathrm{L}^{-1} \mathrm{ZnO}$ ) and without Zn spiking.

The use of $\mathrm{ZnO}$ nanoparticles for effluent treatment clearly resulted in the release of a significant amount of $\mathrm{Zn}$ into the final solution. However, the amount of $\mathrm{Zn}$ released in distilled water after photocatalysis was not directly proportional to the added $\mathrm{ZnO}$ 
concentrations, probably because aggregation phenomena limited nanoparticle dissolution for concentrations equal to or above $0.5 \mathrm{~g} \mathrm{~L}^{-1}$. It is noteworthy that ultrafilterable $\mathrm{Zn}$ concentrations were practically constant between 0.5 and $4 \mathrm{~g} \mathrm{~L}^{-1}$ of added $\mathrm{ZnO}$, indicating the increasing presence of colloidal $\mathrm{Zn}$ (20-30\% of the total filterable concentrations) in these solutions. The percentages of colloidal $\mathrm{Zn}$ in the municipal effluent sample with and without added $\mathrm{ZnO}\left(1 \mathrm{~g} \mathrm{~L}^{-1}\right)$ were about 35 and 50\%, respectively.

\subsection{Toxicity Data}

Toxicity data for treated distilled water and real wastewater spiked with SPY are reported in Figures 5 and 6, respectively. Only the lowest investigated $\mathrm{ZnO}$ concentration $\left(0.1 \mathrm{~g} \mathrm{~L}^{-1}\right)$ presented relatively low toxicity effects, especially in the distilled water scenario. For all the other exposure scenarios in aqueous solutions, tests with A. fischeri, R. subcapitata, and D. magna highlighted effects greater than $45 \%$. These results suggest that the addition of $\mathrm{ZnO}$ could impair by itself the quality of the treated water, independently from the concentration of SPY or the presence of its degradation by-products (Figure 5). Previous investigations report $\mathrm{EC}_{50}$ for SPY of approximately $8000 \mathrm{mg} \mathrm{L}^{-1}$ for $A$. fischeri [26], $4 \mathrm{mg} \mathrm{L}^{-1}$ for R. subcapitata [26,32], and $500 \mathrm{mg} \mathrm{L}^{-1}$ for D. magna [26]. Thus, only R. subcapitata could have been directly impaired by the initial experimental SPY concentration $\left(10 \mathrm{mg} \mathrm{L}^{-1}\right)$. The residual SPY content after $80 \mathrm{~min}$ was about $2.5 \mathrm{mg} \mathrm{L}^{-1}$ in the worst-case scenario (i.e., treatment with $0.1 \mathrm{~g} \mathrm{~L}^{-1} \mathrm{ZnO}$ ) and below $1 \mathrm{mg} \mathrm{L}^{-1}$ for the other concentrations of $\mathrm{ZnO}$. These residual SPY concentrations were well below the $\mathrm{EC}_{50}$ and $\mathrm{EC}_{5}$ values established by [26] for $A$. fischeri (8263 and $1348 \mathrm{mg} \mathrm{L}^{-1}$ ) and D. magna (503 and $70 \mathrm{mg} \mathrm{L}^{-1}$ ), while could be of ecotoxicological significance for $R$. subcapitata ( 4.0 and $0.02 \mathrm{mg} \mathrm{L}^{-1}$ ). In the case of the green alga, SPY concentrations of about $0.3 \mathrm{mg} \mathrm{L}^{-1}$ are expected to cause a $20 \%$ toxic effect, in agreement with the increase in toxicity between $\mathrm{ZnO}$ and $\mathrm{ZnO}+\mathrm{SPY}$ samples for the $0.1 \mathrm{~g} \mathrm{~L}^{-1}$ treatment.

On a species-by-species basis, statistical comparison of toxicity data (Tukey's test) suggests that toxicity levels differed only slightly across the range of $\mathrm{ZnO}$ concentrations. Most importantly, significant levels of toxicity were already detectable at the lowest investigated $\mathrm{ZnO}$ concentration $\left(0.1 \mathrm{mg} \mathrm{L}^{-1}\right)$. Integrating toxic effects across the testing species according to [33], the overall hazard of the tested samples ranged between slight acute $($ score $=2)$ and high acute (score $=3$ ) (Table 2). The observed effects can be explained by $\mathrm{Zn}$ levels in the exposure media as suggested by previous authors [34-37].

The toxicity of the BTW spiked with $1 \mathrm{~g} \mathrm{~L}^{-1}$ of $\mathrm{ZnO}$ was significantly reduced compared to the distilled water scenario (Figure 6). We surmise that part of the Zn released from the catalyst could adsorb onto the organic matter contained in the BWT, thus becoming biologically unavailable. After SPY addition, the toxicity of BTW increased from less than $20 \%$ (for all testing species) to approximately 50\% (A. fischeri) and 35\% (D. magna), while no toxicity was registered from $R$. subcapitata. Following the photocatalytic treatment of BTW spiked with ZnO and SPY, the toxicity disappeared for D. magna, decreased to 35\% for $A$. fischeri, and increased to $>40 \%$ for $R$. subcapitata. These results suggest that UVA degraded the compounds toxic for the water fleas and, partly, bacteria, but generated some others impairing the green algae. Effects were significantly different from [38] for $A$. fischeri nonetheless the considered concentrations were quite similar, considering that the $\mathrm{EC}_{50}$ for A. fischeri was $17 \mathrm{mg} \mathrm{Zn} \mathrm{L}^{-1}$ according to [39]. The observed toxicity could be kept to a minimum or completely removed opting for an immobilized form of $\mathrm{ZnO}$. In a previous study [26] where the SPY degradation was achieved by $\mathrm{TiO}_{2}$ photocatalysis, the hazard for individual organisms was scored from no hazard (mainly for $A$. fischeri) to slight acute (mainly D. magna) and acute (i.e., R. subcapitata). As in the present study, a residual slight acute hazard persisted in the treated samples without any difference linked to the amount of $\mathrm{TiO}_{2}$ used for the treatment process. Besides the by-products' formation, eliminating photocatalysts release to treated effluents, therefore, represents an important challenge for developing environmentally-friendly antibiotic degradation processes, especially when using $\mathrm{ZnO}$-based photocatalysis. 
Table 2. Integration of toxicity results from A. fischeri (Af), R. subcapitata (Rs), and D. magna (Dm) according to [29].

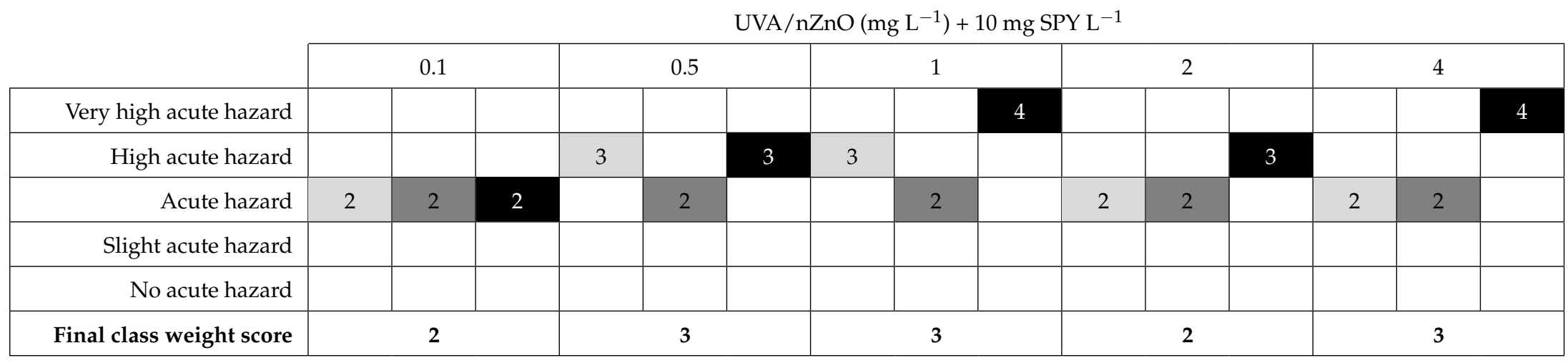

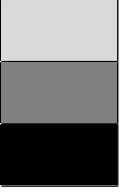

$V$. fischeri $15 \mathrm{~min}$

R. subcapitata

D. magna $48 \mathrm{~h}$
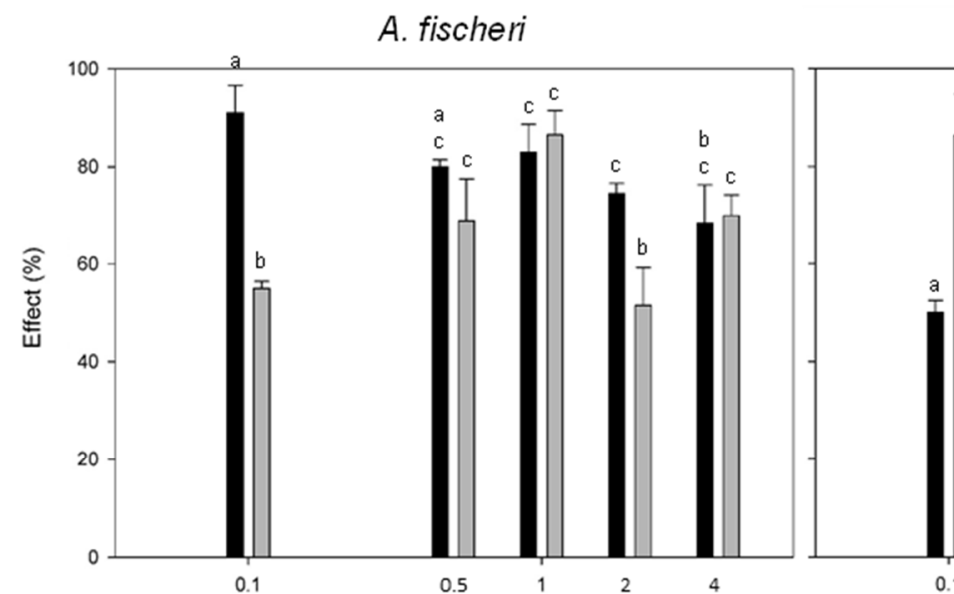

R. subcapitata

D. magna

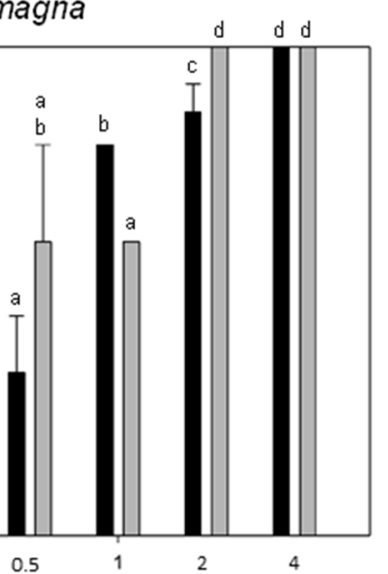

0.5

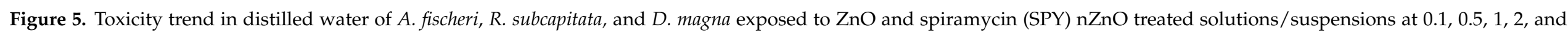
$4 \mathrm{~g} \mathrm{ZnO} \mathrm{L}^{-1}$. Data with different letters (a-d) are significantly different (Tukey's test, $p<0.05$ ). 


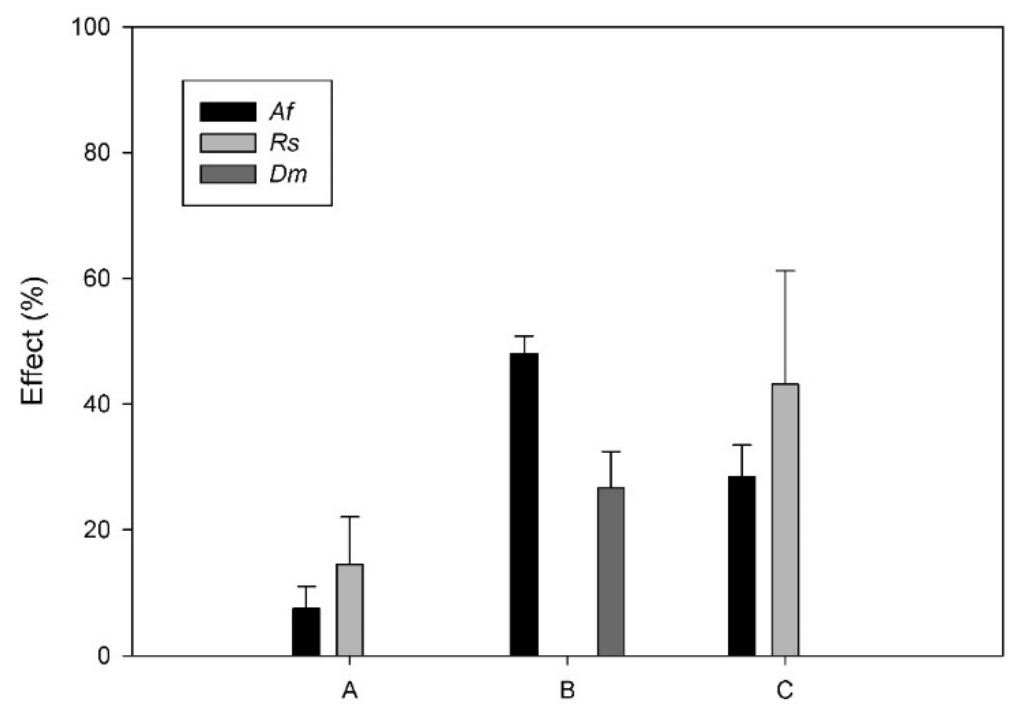

Figure 6. Toxicity trend of A. fischeri (Af), R. subcapitata (Rs) and D. magna (Dm) exposed to A = BTW, $\mathrm{B}=\mathrm{BTW}+10 \mathrm{mg} \mathrm{L}^{-1} \mathrm{SPY}+1 \mathrm{~g} \mathrm{ZnO} \mathrm{L}^{-1}, \mathrm{C}=\mathrm{BTW}+10 \mathrm{mg} \mathrm{L}^{-1}$ SPY-UVA+1 $\mathrm{g} \mathrm{ZnO} \mathrm{L}^{-1}$; $\mathrm{BTW}=$ biologically treated wastewater.

\section{Conclusions}

The degradation of SPY in both spiked aqueous solutions and urban treated wastewater samples by $\mathrm{ZnO}$-assisted photocatalysis was investigated. A high removal rate was reported in both cases, confirming that $\mathrm{ZnO}$ photocatalysis can effectively degrade antibiotics. Treated effluents were tested using a battery of bioassays to verify their actual environmental compatibility. Despite the highly efficient SPY removal, treated effluents posed a significant risk for aquatic organisms because of high residual filterable and ultrafilterable $\mathrm{Zn}$ concentrations. These results confirm the need to systematically combine the development of advanced treatment processes with an ecotoxicological evaluation of the treated water. Moreover, the use of different bioassays at different trophic levels is strongly recommended to achieve an integrated assessment of potential impacts on ecosystems.

The future environmental compatibility of $\mathrm{ZnO}$-based nanomaterials in photocatalytic advanced oxidation processes will largely depend on avoiding the release of soluble $\mathrm{Zn}$ during the selected treatment options.

Author Contributions: Conceptualization, G.L. (Giusy Lofrano), D.A.L.V. and M.C.; statistical analysis G.L. (Giovanni Libralato); validation, M.C., D.A.L.V.; ecotoxicological analysis G.L. (Giovanni Libralato), A.S. and F.C., M.G.; photocatalysis experiments, D.A.L.V., M.C., G.L. (Giusy Lofrano); data curation, G.L. (Giovanni Libralato); writing G.L. (Giusy Lofrano), G.L. (Giovanni Libralato), M.C., D.A.L.V., M.G. All authors have read and agreed to the published version of the manuscript.

Funding: This research received no external funding.

Institutional Review Board Statement: Not applicable.

Informed Consent Statement: Not applicable.

Acknowledgments: The authors would thank the COST ACTION ENTER (ES1205) to support the Short Time Scientific Mission of D.A.L. Vignati to University of Salerno. The assistance of Philippe Rousselle (Université de Lorraine) for the analysis of $\mathrm{Zn}$ is greatly acknowledged.

Conflicts of Interest: The authors declare no conflict of interest. 


\section{References}

1. Lofrano, G.; Libralato, G.; Sharma, S.K.; Carotenuto, M. Nano based photocatalytic degradation of pharmaceuticals. In Nanotechnologies for Environmental Remediation: Applications and Implications; Springer: Berlin/Heidelberg, Germany, 2017 ; pp. $221-238$. [CrossRef]

2. Starling, M.C.V.; Amorim, C.C.; Leão, M.M.D. Occurrence, control and fate of contaminants of emerging concern in environmental compartments in Brazil. J. Hazard. Mater. 2019, 372, 17-36. [CrossRef] [PubMed]

3. Tian, Z.; Palomo, A.; Zhang, H.; Luan, X.; Liu, R.; Awad, M.; Smets, B.F.; Zhang, Y.; Yang, M. Minimum influent concentrations of oxytetracycline, streptomycin and spiramycin in selecting antibiotic resistance in biofilm type wastewater treatment systems. Sci. Total Environ. 2020, 720, 137531. [CrossRef] [PubMed]

4. Yang, W.; Ok, Y.S.; Dou, X.; Zhang, Y.; Yang, M.; Wei, D.; Xu, P. Effectively remediating spiramycin from production wastewater through hydrolyzing its functional groups using solid superacid $\mathrm{TiO}_{2} / \mathrm{SO}_{4}$. Environ. Res. 2019, 175, 393-401. [CrossRef] [PubMed]

5. Calvete, M.J.; Piccirillo, G.; Vinagreiro, C.S.; Pereira, M.M. Hybrid materials for heterogeneous photocatalytic degradation of antibiotics. Coord. Chem. Rev. 2019, 395, 63-85. [CrossRef]

6. World Health Organization. WHO Report on Surveillance of Antibiotic Consumption: 2016-2018 Early Implementation; World Health Organization: Geneva, Switzerland, 2018.

7. United Nations. Political Declaration of the High-Level Meeting of the General Assembly on Antimicrobial Resistance; United Nations: New York, NY, USA, 2016.

8. Versporten, A.; Bolokhovets, G.; Ghazaryan, L.; Abilova, V.; Pyshnik, G.; Spasojevic, T.; Korinteli, I.; Raka, L.; Kambaralieva, B.; Cizmovic, L. Antibiotic use in eastern Europe: A cross-national database study in coordination with the WHO Regional Office for Europe. Lancet Infect. Dis. 2014, 14, 381-387. [CrossRef]

9. Bellino, A.; Lofrano, G.; Carotenuto, M.; Libralato, G.; Baldantoni, D. Antibiotic effects on seed germination and root development of tomato (Solanum lycopersicum L). Ecotoxicol. Environ. Saf. 2018, 148, 135-141. [CrossRef]

10. Lofrano, G.; Meriç, S. A review on occurrence, measurement, toxicity and tannin removal processes from wastewaters. Environ. Eng. Manag. J. 2019, 18, 109-123. [CrossRef]

11. Lofrano, G.; Libralato, G.; Brown, J. Nanotechnologies for Environmental Remediation: Applications and Implications; Springer: Berlin/Heidelberg, Germany, 2017; pp. 1-325. [CrossRef]

12. Rizzo, L.; Agovino, T.; Nahim-Granados, S.; Castro-Alférez, M.; Fernández-Ibáñez, P.; Polo-López, M.I. Tertiary treatment of urban wastewater by solar and UV-C driven advanced oxidation with peracetic acid: Effect on contaminants of emerging concern and antibiotic resistance. Water Res. 2019, 149, 272-281. [CrossRef]

13. Zammit, I.; Vaiano, V.; Ribeiro, A.R.; Silva, A.M.; Manaia, C.M.; Rizzo, L. Immobilised cerium-doped zinc oxide as a photocatalyst for the degradation of antibiotics and the inactivation of antibiotic-resistant bacteria. Catalysts 2019, 9, 222. [CrossRef]

14. O'Neill, J. Antimicrobial Resistance: Tackling a Crisis for the Health and Wealth of Nations; Review on Antimicrobial Resistance: London, UK, 2014.

15. Carotenuto, M.; Libralato, G.; Gürses, H.; Siciliano, A.; Rizzo, L.; Guida, M.; Lofrano, G. Nonylphenol deca-ethoxylate removal from wastewater by UV/H2O2: Degradation kinetics and toxicity effects. Process Saf. Environ. Prot. 2019, 124, 1-7. [CrossRef]

16. Kansal, S.; Singh, M.; Sud, D. Studies on photodegradation of two commercial dyes in aqueous phase using different photocatalysts. J. Hazard. Mater. 2007, 141, 581-590. [CrossRef]

17. Behnajady, M.; Modirshahla, N.; Hamzavi, R. Kinetic study on photocatalytic degradation of CI Acid Yellow 23 by ZnO photocatalyst. J. Hazard. Mater. 2006, 133, 226-232. [CrossRef]

18. Stoimenov, P.K.; Klinger, R.L.; Marchin, G.L.; Klabunde, K.J. Metal oxide nanoparticles as bactericidal agents. Langmuir 2002, 18, 6679-6686. [CrossRef]

19. Dimapilis, E.A.S.; Hsu, C.-S.; Mendoza, R.M.O.; Lu, M.-C. Zinc oxide nanoparticles for water disinfection. Sustain. Environ. Res. 2018, 28, 47-56. [CrossRef]

20. Hwangbo, M.; Claycomb, E.C.; Liu, Y.; Alivio, T.E.; Banerjee, S.; Chu, K.-H. Effectiveness of zinc oxide-assisted photocatalysis for concerned constituents in reclaimed wastewater: 1, 4-Dioxane, trihalomethanes, antibiotics, antibiotic resistant bacteria (ARB), and antibiotic resistance genes (ARGs). Sci. Total Environ. 2019, 649, 1189-1197. [CrossRef] [PubMed]

21. Abada, B.; Alivio, T.E.; Shao, Y.; O'Loughlin, T.E.; Klemashevich, C.; Banerjee, S.; Jayaraman, A.; Chu, K.-H. Photodegradation of fluorotelomer carboxylic 5: 3 acid and perfluorooctanoic acid using zinc oxide. Environ. Pollut. 2018, 243, 637-644. [CrossRef] [PubMed]

22. Ghosh, M.; Manoli, K.; Shen, X.; Wang, J.; Ray, A.K. Solar photocatalytic degradation of caffeine with titanium dioxide and zinc oxide nanoparticles. J. Photochem. Photobiol. A Chem. 2019, 377, 1-7. [CrossRef]

23. Daneshvar, N.; Salari, D.; Khataee, A. Photocatalytic degradation of azo dye acid red 14 in water on $\mathrm{ZnO}$ as an alternative catalyst to TiO2. J. Photochem. Photobiol. A Chem. 2004, 162, 317-322. [CrossRef]

24. Meng, F.; Liu, Y.; Wang, J.; Tan, X.; Sun, H.; Liu, S.; Wang, S. Temperature dependent photocatalysis of g-C3N4, TiO2 and ZnO: Differences in photoactive mechanism. J. Colloid Interface Sci. 2018, 532, 321-330. [CrossRef]

25. Kanakaraju, D.; Glass, B.D.; Oelgemöller, M. Advanced oxidation process-mediated removal of pharmaceuticals from water: A review. J. Environ. Manag. 2018, 219, 189-207. [CrossRef] 
26. Lofrano, G.; Libralato, G.; Casaburi, A.; Siciliano, A.; Iannece, P.; Guida, M.; Pucci, L.; Dentice, E.F.; Carotenuto, M. Municipal wastewater spiramycin removal by conventional treatments and heterogeneous photocatalysis. Sci. Total Environ. 2018, 624, 461-469. [CrossRef]

27. García-Espinoza, J.D.; Nacheva, P.M. Degradation of pharmaceutical compounds in water by oxygenated electrochemical oxidation: Parametric optimization, kinetic studies and toxicity assessment. Sci. Total Environ. 2019, 691, 417-429. [CrossRef]

28. He, S.; Han, C.; Wang, H.; Zhu, W.; He, S.; He, D.; Luo, Y. Uptake of arsenic (V) using alumina functionalized highly ordered mesoporous SBA-15 (Al x-SBA-15) as an effective adsorbent. J. Chem. Eng. Data 2015, 60, 1300-1310. [CrossRef]

29. Martinez-Costa, J.I.; Leyva-Ramos, R.; Padilla-Ortega, E. Sorption of diclofenac from aqueous solution on an organobentonite and adsorption of cadmium on organobentonite saturated with diclofenac. Clays Clay Miner. 2018, 66, 515-528.

30. Lee, K.M.; Lai, C.W.; Ngai, K.S.; Juan, J.C. Recent developments of zinc oxide based photocatalyst in water treatment technology: A review. Water Res. 2016, 88, 428-448. [CrossRef]

31. Gomez-Solís, C.; Ballesteros, J.; Torres-Martínez, L.; Juárez-Ramírez, I.; Torres, L.D.; Zarazua-Morin, M.E.; Lee, S.W. Rapid synthesis of $\mathrm{ZnO}$ nano-corncobs from Nital solution and its application in the photodegradation of methyl orange. J. Photochem. Photobiol. A Chem. 2015, 298, 49-54. [CrossRef]

32. Minguez, L.; Pedelucq, J.; Farcy, E.; Ballandonne, C.; Budzinski, H.; Halm-Lemeille, M.-P. Toxicities of 48 pharmaceuticals and their freshwater and marine environmental assessment in northwestern France. Environ. Sci. Pollut. Res. 2016, 23, $4992-5001$. [CrossRef] [PubMed]

33. Persoone, G.; Marsalek, B.; Blinova, I.; Törökne, A.; Zarina, D.; Manusadzianas, L.; Nalecz-Jawecki, G.; Tofan, L.; Stepanova, N.; Tothova, L. A practical and user-friendly toxicity classification system with microbiotests for natural waters and wastewaters. Environ. Toxicol. Int. J. 2003, 18, 395-402. [CrossRef]

34. Khosravi-Katuli, K.; Lofrano, G.; Pak Nezhad, H.; Giorgio, A.; Guida, M.; Aliberti, F.; Siciliano, A.; Carotenuto, M.; Galdiero, E.; Rahimi, E.; et al. Effects of ZnO nanoparticles in the Caspian roach (Rutilus rutilus caspicus). Sci. Total Environ. 2018, 626, 30-41. [CrossRef]

35. Manzo, S.; Miglietta, M.L.; Rametta, G.; Buono, S.; Di Francia, G. Embryotoxicity and spermiotoxicity of nanosized ZnO for Mediterranean sea urchin Paracentrotus lividus. J. Hazard. Mater. 2013, 254, 1-9. [CrossRef]

36. Blinova, I.; Ivask, A.; Heinlaan, M.; Mortimer, M.; Kahru, A. Ecotoxicity of nanoparticles of CuO and ZnO in natural water. Environ. Pollut. 2010, 158, 41-47. [CrossRef] [PubMed]

37. Zhang, L.L.; Chen, B.; Xie, L.L.; Li, Z.F. Study on the antimicrobial properties of ZnO suspension against Gram-positive and Gram-negative bacteria strains. Adv. Mater. Res. 2011, 393-395, 1488-1491. [CrossRef]

38. Vela, N.; Calín, M.; Yáñez-Gascón, M.J.; Garrido, I.; Pérez-Lucas, G.; Fenoll, J.; Navarro, S. Photocatalytic oxidation of six endocrine disruptor chemicals in wastewater using $\mathrm{ZnO}$ at pilot plant scale under natural sunlight. Environ. Sci. Pollut. Res. 2018, 25, 34995-35007. [CrossRef] [PubMed]

39. Schiavo, S.; Oliviero, M.; Li, J.; Manzo, S. Testing ZnO nanoparticle ecotoxicity: Linking time variable exposure to effects on different marine model organisms. Environ. Sci. Pollut. Res. 2018, 25, 4871-4880. [CrossRef] [PubMed] 